\title{
An Empirical Assessment of the Effect of Taxes and Interest Rate on Economic Growth in Jordan: An Application of Dynamic Autoregressive-Distributed Lag
}

\author{
Bashar Younis Alkhawaldeh ${ }^{1}$, Suraya Mahmood ${ }^{1} \&$ Aminu Hassan Jakada ${ }^{1}$ \\ ${ }^{1}$ Faculty of Business and Management, Universiti Sultan Zainal Abidin, Terengganu, Malaysia \\ Correspondence: Suraya Mahmood, Faculty of Business and Management, Universiti Sultan Zainal Abidin, \\ Terengganu, Malaysia.
}

Received: May 4, 2020

Accepted: June 12, 2020

Online Published: June 16, 2020

doi:10.5430/rwe.v11n3p92

URL: https://doi.org/10.5430/rwe.v11n3p92

\begin{abstract}
This study aims to examine the effect of taxes and interest rate on economic growth in Jordan by employing the time series data from 1970-2019. Furthermore, this study applies the Augmented Dickey-Fuller, Phillips-Perron, Saikonen and Lütkepohl and Zivot-Andrews test of unit root. Moreover, the study uses cointegration test developed by Gregory and Hansen to investigate the long-run relationship and the dynamic autoregressive distributive lags were used for the estimation result. The long run and short-run estimates reveal the positive and negative effects of taxes and the interest rate on economic growth respectively. While the 1997 Asian financial crisis and 2015 food crisis show a negative effect on economic growth. Based on the findings, the study recommends that the government authorities in Jordan should lower the interest rate that will increase the investment in order to have faster economic growth. The government should urgently plan to broaden the tax base to stimulate economic growth in Jordan. Regulators should encourage banks to start raising capital immediately to strengthen capital ratios well above prudential norms, and prepare schemes for public recapitalization and, where appropriate, public purchases of non-performing assets. The next policy fulfils the government's need to enhance agricultural productivity through better technology to ensure long-term food security and reduce poverty, as well as help to boost economic growth.
\end{abstract}

Keywords: taxes, interest rate, dynamic autoregressive-distributed lag, Saikonen and Lütkepohl, Zivot-Andrew

\section{Introduction}

In macroeconomics, the role of fiscal policy in the long-run growth cycle has been central particularly since the emergence of endogenous growth models. As engines of sustainable growth, numerous authors have concentrated on different styles of fiscal policy. A great deal of empirical research has also been done to check the theoretical model predictions, but the findings vary significantly between the studies. Levine-Renelt (1992) and Agell et al. (1997) pointed out the sensitivity of the results to changes in the control variables collection. An issue with most studies is that they do not check the growth impact of fiscal policy given the nature of both taxes and government expenditure (government funding for fuel and wheat), i.e. they concentrate on one side of government action ignoring, at least partially, the other side. Kneller et al. (1999), Bleaney et al. (2001), were the first to demonstrate that studies which do not take into consideration of both sides of the budget suffer significant biases in the coefficient results, supported by others (Angelopoulos et al., 2007, Romero-Avila, Strauch, 2008).

Nonetheless, monetary policy is the monetary authorities' concerted intervention to control the amount, expense, and availability of money credit to achieve desired internal and external balances of macroeconomic objectives. The intervention is achieved by changing money supply and/or interest rates with the goal of regulating the liquidity in the economy. Consequently, monetary policy as an economic management tool for achieving sustainable economic growth and development was the initiative of nations and the systematic articulation of how money affects economic aggregates dates back to Adams Smith's time and was later advocated by the monetary economists (Auclert, 2019).

After revealing the role of monetary policy in affecting macroeconomic goals such as economic growth, price stability, balance of payments equilibrium and host of other goals, monetary authorities are being saddled with the burden of using monetary policy to develop their economies. Economic growth could be described as the increase in the number of products and services at a particular time in a given country. This of course means that economic 
development happens when a country's real per capita income rises over time. In every successive period of time a rising economy produces goods and services, indicating that the productive potential of the economy is that. Broadly speaking, economic growth implies growing people's living standards and rising wealth distribution inequality (Farhi, \& Werning, 2019).

In 1998, the Jordanian economy entered a strike, which started in South East Asia. In addition, even before the pre-summer of 1997, requests had been made regarding the reasonableness of specific monetary strategies adopted by the countries of South East Asia, especially the easy-going process of settling their scale of conversion. Refugees in camps need humanitarian assistance to ensure minimum requirements are met for services like housing, food, water, education, and security. Refugees living in host communities are disproportionately dependent on social services and foreign assistance, or rely on negative coping mechanisms such as limiting food intake, limiting children's access to education, participating in illegal activity, child labor or allowing early marriage. Furthermore, Syrian workers in Jordan were able to accept low pay and harsh working conditions, thereby competing with Jordanians in some industries and further increasing the informality of the labor market (Saikal, et al., 2020)

Simultaneously, the requirements of distraught Jordanian individuals have developed quickly, with expanded asset request stressing the limit of the national government to meet its residents ' needs. Also, the extreme crumbling in the nature of administrations gave across different basic areas, including wellbeing, instruction, sanitation, and civil administrations, influences Syrians and Jordanians in have networks similarly. Around 200 state funded schools run twofold move classes to reduce stuffing, subsequently influencing the nature of training that all youngsters get. Wellbeing focuses and medical clinics can't stay aware of the expansion in the populace they serve. Roughly $1,441,084$ immunizations were given to Syrian displaced people, and in 2015, around 251,000 Syrian patients utilized the offices of medical clinics or wellbeing focuses at the Ministry of Health. In addition, $19 \%$ of strong waste can't be discarded appropriately in territories intensely populated by Syrians because of absence of landfill limit and interest for water assets has expanded by as much as $40 \%$. In some northern regions, water per capita dropped by 27 percent.

The nearness of a high number of Syrians in have networks is additionally significantly affecting the work advertise, expanding rivalry for accessible openings for work, bringing down pay levels and fueling effectively poor working conditions for low paid occupations. This constrained numerous defenseless Jordanians to go to programs for social assurance, further extending these plans ' limit. At last, albeit a few areas may have profited by the expansion in populace, the general monetary effect of the emergency has been impeding. This circumstance disintegrates Jordan's improvement increases over the previous decades as arranged turn of events, support, and development of new speculations, administrations, and foundation are relinquished to pay for relieving the emergency ' sway (Abu-Awwad, et al., 2020). Hence, this study examined the effect of taxes, interest rate, Asian financial crisis and food crisis on economic growth in Jordan from 1970-2019.

\section{Data and Methodology}

Using the 1970-2019 annual data to analyze the relationship between interest rate, taxes, Asian crisis and economic growth food crisis for the case of Jordan with data collected from the World Development Indicator CD-ROM (WDI 2020). The system STATA 15, J-Multi, and EViews 11 were used for the analysis. Economic growth is a proxy for the growth of real gross domestic product (RGDP), the lending rate (IR) as an measure of interest. This research followed the Cobb-Douglas Model for Growth:

$$
Q_{t}=C_{t}^{\varphi}\left(R_{t} L F_{t}\right)^{1-m}
$$

This model has been for several empirical literature for example Ang (2008), Sharma (2010), Menyah and Wolde-Rufael (2010), Shahbaz et al. (2012), Ahmad, et al., (2018), and Ahmad, et al., (2020) among others, include the taxes, and interest, in their empirical model to examine the effect of them on economic growth. While they find generally that taxes, and interest rate stimulate economic growth. Hence, the current study extends the equation (1) above by including two crises (1997 Asian financial crisis and 2015 Food crisis) consider the following functional form:

$$
L N R G D P_{t}=f\left(L N T_{t}, L N I R_{t}, T B_{1997}, T B_{2015}\right)
$$

This study will transform all the variables into natural logarithms to capture their elasticity value and set them free from the problem of heteroscedasticity. The empirical version of the model and the econometric analysis, the functional equation is as follow:

$$
L N R G D P_{t}=\theta_{0}+T B_{1997}+T B_{2015}+\vartheta_{1} L N T_{t}+\vartheta_{2} L N I R_{t}+\varepsilon_{t}
$$


Additionally, a unit root test is performed to avoid a bias parameter or false regression. Augmented Dickey-fuller (ADF), Philip-Perron (PP), Saikonen and Lütkepohl (SL), and Zivot Andrews (ZA) were used in this analysis to check whether or not the data had a unit root. In addition, the cointegration analysis would be used in terms of analyzing the long-run relationship between the variables. This study will Gregory and Hansen (1996) Co-integration to determine the long run effect among the independent variables and dependent variable. In this study, to examine the short run and long run estimates, Dynamic ARDL models was employed. As opposed to the complexities of existing ARDL models in looking at the impact of short-and since quite a while ago run in complex model determinations, Jordan and Philips (2018) presented a novel unique animated ARDL model equipped for evaluating, invigorating and naturally plotting expectations of counterfactual change in one regressor on the needy variable while holding different regressors consistent. To apply the dynamic invigorated ARDL procedure, the information arrangement for the model estimation ought to be coordinated of request one and cointegrated, for which the factors in this work meet the prerequisites.

\section{Results and Discussion}

\subsection{Descriptive statistics and Correlation Analysis}

Table 1 presents the descriptive statistics. The average values of LNRGDP, LNIR and LNT are $2.45 \%, 2.01 \%$ and $20.49 \% \%$ respectively. The maximum numbers of LNRGDP, LNIR and LNT were 5.56, 2.55 and 22.26, while the minimum numbers were $0.44,-0.60$ and 17.68 . The probability values of Jarque-Bera showed that LNIR was not normality distributed, while LNRGDP and LNT were normally distributed.

Table 1. Descriptive statistics

\begin{tabular}{lccc}
\hline & $L N R G D P$ & $L N I R$ & $L N T$ \\
\hline Mean & 2.456 & 2.009 & 20.49 \\
\hline Median & 2.119 & 2.148 & 20.65 \\
\hline Maximum & 5.555 & 2.547 & 22.26 \\
\hline Minimum & 0.442 & -0.604 & 17.68 \\
\hline Std. Dev. & 1.526 & 0.525 & 1.234 \\
\hline Skewness & 0.736 & -2.849 & -0.526 \\
\hline Kurtosis & 2.415 & 13.83 & 2.717 \\
\hline Jarque-Bera & 5.232 & $312.1^{*}$ & 2.480 \\
\hline Probability & $(0.073)$ & $(0.000)$ & $(0.289)$ \\
\hline
\end{tabular}

Table 2 shows the correlation analysis. The results reveal that the correlation between interest rate, taxes and economic growth is negatively very weak -0.12 and -0.18 respectively. Moreover, the correlation between taxes and interest rate indicate very weak positive.

Table 2. Correlation Analysis

\begin{tabular}{cccc}
\hline \multicolumn{5}{c}{ LNRGDP } & LNIR & LNT \\
\hline LNRGDP & 1.000 & & \\
\hline \multicolumn{5}{c}{} \\
\hline LNIR & -0.122 & 1.000 & \\
\hline LNT & $(0.395)$ & & 1.000 \\
\hline & $-0.182^{*}$ & 0.168 & \\
\hline
\end{tabular}

\subsection{Unit Root Testing}

Unit root tests are conducted in the study to determine whether there are any variables integrated of order two which are not ideal for Gregory and Hansen (1996) Co-integration and DARDL estimations. The results of unit root tests 
demonstrate, as can be seen from Table 3, that series are non-stationary at levels but become stationary at first differences; they are said to be integrated in first order, I(1) In this case, it was concluded that the presence of cointegration relationship between these series can be verified because the series being considered are incorporated in the same order.

Table 3. Result of Unit Root Test

\begin{tabular}{ccccccccccc}
\hline & \multicolumn{4}{c}{ ZA } & \multicolumn{2}{c}{ SL } & \multicolumn{2}{c}{ ADF } & \multicolumn{2}{c}{ PP } \\
\cline { 2 - 11 } Variables & Level & Brk Date & $1^{\text {st }}$ Diff & Brk Date. & Level & $1^{\text {st }}$ Diff & Level & $1^{\text {st }}$ Diff & Level & $1^{\text {st }}$ Diff \\
\hline$L N R G D P$ & -3.805 & 1980 & $-16.38^{*}$ & 1992 & 0.21 & $6.52^{*}$ & -1.834 & $-11.80^{*}$ & -1.999 & $-13.51^{*}$ \\
\hline$L N I R$ & -3.083 & 1979 & $-15.79^{*}$ & 1979 & 2.52 & $9.81^{*}$ & -2.231 & $-8.169^{*}$ & -2.167 & $-9.729^{*}$ \\
\hline$L N T$ & -3.223 & 2005 & $-8.460^{*}$ & 1989 & 1.39 & $5.20^{*}$ & -2.366 & $-5.973^{*}$ & -2.589 & $-5.971^{*}$ \\
\hline
\end{tabular}

\subsection{Cointegration Test}

The cointegration study was used in terms of analyzing the long-run relationship between the variables. This research utilized co-integration between Gregory and Hansen (1996) to assess the long-term influence between independent variables and dependent variable. The need for a co-integration check is necessary to assist in the establishment of long-term series bonds. For structural breaks, the standard cointegration check (see Johansen, 1991; Johansen \& Juselius, 1990) fails to account. Thus, in the econometrics literature, new breeds of the cointegration test are available that help bypass erroneous analysis and help account for the breaks (Gregory \& Hansen, 1996; Westerlund \& Edgerton, 2007).

Therefore, this analysis employs cointegration check Gregory and Hansen (1996), which accounts for structural breaks. The result is described in the blow to table 4. The result shows that in Jordan there is a co-integration relationship between interest rate, taxes, and economic development with the presence of numerous breaks at both point, trend and regime. That implies that there is a long-term co-integration relationship between interest rate, taxes and economic development. This result is consistent with Canicio and Zachary (2014), Fahd Ben Abdullah Alhwimani (2015), However, Aghion, Akcigit, Cage, and Kerr, (2016), Al-Araj, Shaher (2017), Moyo and Le Roux, (2018), Jacobs, Ogawa, Sterken, and Tokutsu (2019)

Table 4. Gregory and Hansen (1996) Cointegration Test Result

\begin{tabular}{ccc}
\hline & T-Statistics & Date \\
\hline Level & & \\
\hline $\mathrm{ADF}$ & $-5.03^{* *}$ & 1984 \\
\hline $\mathrm{Zt}$ & $-5.65^{*}$ & 1981 \\
\hline $\mathrm{Za}$ & $-39.52^{* *}$ & 1981 \\
\hline $\mathrm{Trend}$ & & \\
\hline $\mathrm{ADF}$ & $-5.26^{* *}$ & 2001 \\
\hline $\mathrm{Zt}$ & $-5.72^{*}$ & 1981 \\
\hline $\mathrm{Za}$ & -40.10 & 1981 \\
\hline $\mathrm{Regime}$ & & \\
\hline $\mathrm{ADF}$ & $-5.06^{* *}$ & 1984 \\
\hline $\mathrm{Zt}$ & $-5.51^{*}$ & 1981 \\
\hline $\mathrm{Za}$ & $-38.31^{* *}$ & 1981 \\
\hline
\end{tabular}

\subsection{Long Run and Short Run Estimates}

Table 5 represents the Long-run and Short-run results. In the long-run coefficient for $L N I R_{t}, \mathrm{~TB}_{1}$, and $\mathrm{TB}_{2}$ are negative and significant at $1 \%$ and $5 \%$ respectively, while, the coefficients for $L N T_{t}$ is positive and statistically significant at $5 \%$. The signs of all the variables are line with the theoretical predictions. However, in the short run the coefficients for both 
$L N I R_{t}, \mathrm{~TB}_{1}$, and $\mathrm{TB}_{2}$ are negative and significant at $1 \%$ and $5 \%$ respectively. On the other hand, the coefficients for $L N T_{t}$ is positive and statistically significant at 5\%. A $1 \%$ increase in interest rate will lead to $0.239 \%$ and $0.789 \%$ decrease in the economic groeth in both short run and long run. Conversely, A 1\% decrease in 1997 Asian Financial Crisis and 2015 Food Crisis will lead to $0.543 \%$ and $0.234 \%, 0.126 \%$ and $0.332 \%$ increase in the economic groeth in both short run and long run respectively. A $1 \%$ increase in taxes would also lead to an rise in economic growth of 0.219 per cent and 0.617 per cent. In addition, the diagnostic test showed that the values of chi-square suggested the lack of serial association and heteroscedasticity. This also shows that the model is defined correctly, and that the sequence is distributed normally. Consequently the tests for the diagnostic test do not refute the null hypothesis. The $\mathrm{R}^{2}$ value indicates that the independent variables explained 63 per cent of the dependent variable.

Table 5. Estimates results

\begin{tabular}{cc}
\hline \multicolumn{2}{c}{ Dependent variable: $L N G D P_{t}$} \\
\hline Variables & Coefficients \\
\hline$L N I R_{t}$ & $-0.239^{*}$ \\
\hline$\Delta L N I R_{t}$ & $-0.789^{* *}$ \\
\hline$L N T_{t}$ & $0.219^{* *}$ \\
\hline$\Delta L N T_{t}$ & $0.617^{* *}$ \\
\hline$L N T B_{1997}$ & $-0.543^{*}$ \\
\hline$\Delta L N T B_{1997}$ & $-0.234^{*}$ \\
\hline$L N T B_{2015}$ & $-0.126^{*}$ \\
\hline$\Delta L N T B_{2015}$ & $-0.332^{*}$ \\
\hline \multicolumn{2}{c}{} \\
\hline $\mathrm{R}^{2}$ & \\
\hline Adj-R ${ }^{2}$ & \\
\hline F-Statistics & $6.250(0.000)$ \\
\hline$\gamma_{\text {ser }}$ & $0.522(0.770)$ \\
\hline$\gamma_{\text {Hetr }}$ & $0.938(0.451)$ \\
\hline$\gamma_{\text {Nor }}$ & $0.136(0.938)$ \\
\hline \multicolumn{2}{c}{} \\
\hline
\end{tabular}

\section{Discussion, Conclusion and Recommendations}

The goal of the study is to investigate the effects of taxes and interest rate on economic growth in Jordan. Research on this subject has also been regarded as a big concern for policy makers and the government. The empirical outcomes of the study reveal that interest rate is related negatively with economic growth while taxes is positively influencing the level of economic growth both in the short run and long run. According to the result lower interest rate is capable of enhancing the level of economic activities while the more the amount of taxes collected by the government the higher would be the level of economic growth. Henceforth in the case of known structural breaks, the 1997 Asian financial crisis and the 2015 food crisis is having a negative relationship with the economic growth, meaning occurrence of the two crisis decrease the rate of economic activities in Jordan. This study came out with empirical evidence that will help to understand the relationship between variables used in the Jordan economy model drawing from 1990 through 2013.

Based on the research findings, the study recommends that reforms be implemented by the Nigerian authorities to enhance the role of interest rates in mobilizing funds for investment purposes. That can be done through a complete interest rate regulation. This is for economic performance over the long term. In the same vein, the Nigerian authorities should lower the interest rate that will increase the investment in order to have faster economic growth. It is necessary to see the policy direction of interest rate, investment, not only in the context of price and financial stability but also in improving development in Nigeria.

According to the findings, in order to bring about economic development in Jordan, it will be necessary to increase the taxes. In addition, the government should urgently plan to broaden the tax base to stimulate economic growth in Jordan. The Jordanian Government will maintain favorable tax rates that are adequate to produce adequate revenue 
to fund the growth of human resources and infrastructure. Government agencies should effectively design tax collection procedures, as they contribute to economic growth as reported in the findings.

Thus far, Jordan has prevented a systemic financial crisis and financial authorities need to step up vigilance and establish contingency plans to prevent one from forming. Jordan's government should establish a Jordan Financial Stability Dialog including officials from the finance ministry, officials from central bankers, and financial market regulators and supervisors to facilitate policy coordination in the financial sector. Regulators need to step up their monitoring of bank solvency, have clear policies in place to deal with stressed institutions, encourage banks to increase transparency by reporting key financial indicators more regularly and timely, and strengthen regulatory standards for liquidity risk management. Extending and formalizing official bank and other deposit guarantees may be seen as short-term steps. Regulators should encourage banks to start raising capital immediately to strengthen capital ratios well above prudential norms, and prepare schemes for public recapitalization and, where appropriate, public purchases of non-performing assets. In the extreme case of a credit crunch, the authorities should take steps necessary to prevent a spiraling downward from feeding into the real sector. It is a particularly important task to avoid a credit crunch for SMEs and for trade-related activities.

Nonetheless, food security also has an impact on economic growth in terms of life expectancy, total employment and poverty, while life expectancy and total employment with better food security have a positive impact on economic growth, and poverty reduction will occur as a result of improved food security boosting economic growth, particularly in developing countries. Food protection measures intended to fuel economic growth. First, there are many initiatives and projects to be introduced in order to strengthen food security and accelerate economic development. There are three significant government needs, according to the Asian Development Bank (2012), to provide food-based safety nets and related social protection programs. This plan aims at automatically stabilizing economic growth in order to cope with the recent food crisis. Furthermore, this program is also known to feed the emergency jobs program which due to natural hazard shock can give effective relief through public-private food security funds and crop insurance. The next policy fulfills the government's need to enhance agricultural productivity through better technology to ensure long-term food security and reduce poverty, as well as help to boost economic growth.

\section{References}

Abu-Awwad, M., AL-Omoush, S., Shqaidef, A., Hilal, N., \& Hassona, Y. (2020). Oral health-related quality of life among Syrian refugees in Jordan: a cross-sectional study. International Dental Journal, 70(1), 45-52.

Agell, J., Lindh, T., \& Ohlsson, H. (1997). Growth and the public sector: A critical review essay. European Journal of Political Economy, 13(1), 33-52.

Aghion, P., Akcigit, U., Cagé, J., \& Kerr, W. R. (2016). Taxation, corruption, and growth. European Economic Review, 86, 24-51.

Ahmad, A. U., Ismail, S., Jakada, A. H., Farouq, I. S., Muhammad, A. A., Mustapha, U. A., ... \& Muhammad, A. (2020). A Heterogeneous Relationships between Urbanization, Energy Consumption, Economic Growth on Environmental Degradation: Panel Study of Malaysia and Selected ASEAN+ 3 Countries. Journal of Environmental Treatment Techniques, 8(1), 573-581.

Ahmad, A. U., Loganathan, N., Streimikiene, D., \& Hassan, A. A. G. (2018). Financial instability, trade openness and energy prices on leading African countries sustainable growth. Economic Computation and Economic Cybernetics Studies and Research, 52(1), 127-142.

Al-Araj, R. S., \& Shaher, R. (2017). Impact of Interest Rate in the Economy from the Viewpoints of Banking Managers: Empirical Evidence from Jordan. International Journal of Business and Social Research, 7(4), $15-28$.

Ang, J. B. (2008). What are the mechanisms linking financial development and economic growth in Malaysia?. Economic Modelling, 25(1), 38-53.

Angelopoulos, K., Economides, G., \& Kammas, P. (2007). Tax-spending policies and economic growth: theoretical predictions and evidence from the OECD. European Journal of Political Economy, 23(4), 885-902.

Auclert, A. (2019). Monetary policy and the redistribution channel. American Economic Review, 109(6), 2333-67.

Bleaney, M., Gemmell, N., \& Kneller, R. (1999). Growth, Public Policy and the Government Budget Constraint: Evidence from OECD Countries (No. 9814). Discussion Paper. 
Bleaney, M., Gemmell, N., \& Kneller, R. (2001). Testing the endogenous growth model: public expenditure, taxation, and growth over the long run. Canadian Journal of Economics/Revue canadienne d'économique, 34(1), 36-57.

Dzingirai Canicio, T. Z. (2014). Causal relationship between government tax revenue growth and economic growth: a case of Zimbabwe (1980-2012). Journal of Economics and Sustainable Development, 13-15.

Farhi, E., \& Werning, I. (2019). Monetary policy, bounded rationality, and incomplete markets. American Economic Review, 109(11), 3887-3928.

Gregory, A. W., \& Hansen, B. E. (1996). Practitioners corner: tests for cointegration in models with regime and trend shifts. Oxford Bulletin of Economics and Statistics, 58(3), 555-560.

Jacobs, J., Ogawa, K., Sterken, E., \& Tokutsu, I. (2019). Public Debt, Economic Growth and the Real Interest Rate: A Panel VAR Approach to EU and OECD Countries. Applied Economics, 1-18.

Johansen, S. (1991). Estimation and hypothesis testing of cointegration vectors in Gaussian vector autoregressive models. Econometrica: Journal of the Econometric Society, 1551-1580.

Johansen, S., \& Juselius, K. (1990). Maximum likelihood estimation and inference on cointegration-with applications to the demand for money. Oxford Bulletin of Economics and Statistics, 52(2), 169-210.

Levine, R., \& Renelt, D. (1992). A sensitivity analysis of cross-country growth regressions. The American Economic Review, 942-963.

Menyah, K., \& Wolde-Rufael, Y. (2010). CO2 emissions, nuclear energy, renewable energy and economic growth in the US. Energy Policy, 38(6), 2911-2915.

Moyo, C., \& Le Roux, P. (2018). Interest rate reforms and economic growth: the savings and investment channel.

Romero-Avila, D., \& Strauch, R. (2008). Public finances and long-term growth in Europe: Evidence from a panel data analysis. European Journal of Political Economy, 24(1), 172-191.

Saikal, S. L., Ge, L., Mir, A., Pace, J., Abdulla, H., Leong, K. F., ... \& Padovese, V. (2020). Skin disease profile of Syrian refugees in Jordan: a field-mission assessment. Journal of the European Academy of Dermatology and Venereology, 34(2), 419-425.

Shahbaz, M., Zeshan, M., \& Afza, T. (2012). Is energy consumption effective to spur economic growth in Pakistan? New evidence from bounds test to level relationships and Granger causality tests. Economic Modelling, 29(6), 2310-2319.

Sharma, S. S. (2010). The relationship between energy and economic growth: empirical evidence from 66 countries. Applied Energy, 87(11), 3565-3574.

Westerlund, J., \& Edgerton, D. L. (2007). New improved tests for cointegration with structural breaks. Journal of Time Series Analysis, 28(2), 188-224. 